Si el umbral se mueve, se mueven

las puertas.

Pero ya no hay

umbral. Ya no hay "adentro"

y

"afuera"...

(Transcripción / traducción de una entrevista con Pierre Huyghe)

\title{
ABISINIA DESKTOP
}

1

Un plano inclinado.
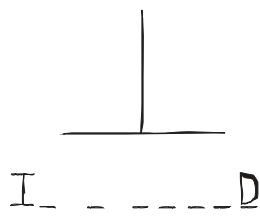

[Le dormeur du bois] $]$

Un spelling contest una soga un libro de texto.

El gis, el pizarrón.

Trazar verticalmente el horizonte simbólico@; traducir / acantilar las letras: el valle / el bosque; las dos balas / la soga; heroísmo C / deserción

(pero, ¿también el ejército francés ahorcaba a sus traidores?, y si sí, ¿de quién son los derechos?)

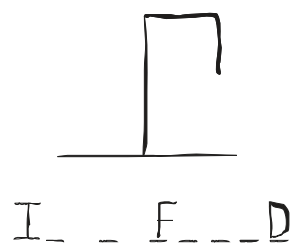


JULIÁN HERBERT

(y ¿qué es que este cadáver azul y de uniforme@ pueda morder los labios de la bella en la rueca, un chantaje Walt Disney(C, una yegua de la noche?)

así lo sublime progresaría -como cae, como decae- por un plano inclinado: línea que cruza del valle al ${ }^{\circledR}$, del soneto al $@$, de la preceptiva a la TM:

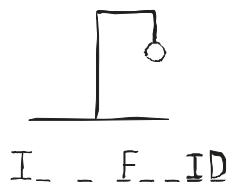

reunir el timbre:

re-usar la derrota:

y el enigma de que un verso se vuelva más preciso ahora que es más pobre:

Nature, berce-le chaudement: il a froid:

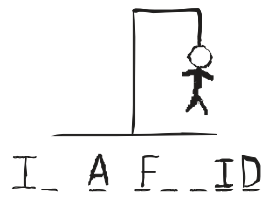

[No por tener monitos deja de ser un curso de lenguaje. Francés Módulo 5. Tarea: intenta traducir "Le dormeur du val"] 


\section{2}

Rimbaud no sabe qué hacer acá.

Es un doguito feo acá, es viejo;

ha echado un poco de papada.

Rimbaud es un tambor rasgado acá, un tan poco cantar, un cogote que la tierra no bendice. Está enfermo.

Lo ha mosqueado la fiebre.

Le ha caído desgracia hasta en quitarle una miseria de dinero bienhabido.

No lo queremos

acá a este Rimbaud mesié tan quebradizo. A este viejo. Que los blancos se lo lleven a su casa.

Nosotros solo queremos

una voz:

nos cante,

nos diga dónde fue el tambor, nos diga dónde.

Y escoja usted su taparrabo, caballero. 